\begin{tabular}{|c|c|c|}
\hline Dinamika Journal, Vol. 2 No. 2,2020 \\
ISSN ONLINE : 2686-2158 \\
\hline
\end{tabular}

\title{
PENINGKATAN EKO-EFISIENSI DAN PRODUKTIVITAS INDUSTRI KECIL DAN MENENGAH (IKM) TAHU DI DESA DUKUH KECAMATAN MANTRIJERON YOGYAKARTA
}

\section{Dwi Agustina Kurniawati*, Cahyono Sigit Pramudyo, Trio Yonathan Tejakusuma, Rillo Pambudi}

\author{
Program Studi Teknik Industri, Fakultas Sains dan Teknologi, \\ Universitas Islam Negeri Sunan Kalijaga, Yogyakarta, Indonesia \\ *Corresponding author: dwi.kurniawati@uin-suka.ac.id \\ Received 7 April 2020; Accepted 21 April 2020; Available online 27 April 2020
}

\begin{abstract}
Abstrak
Perkembangan industri pada era ini semakin pesat dengan meningkatnya kebutuhan pokok khususnya kebutuhan pangan salah satunya yaitu tahu. Efisiensi produksi adalah hal yang sangat penting bagi perusahaan dalam memenangkan persaingan, termasuk dalam hal ini adalah industri tahu. Dengan perkembangan industri yang semakin pesat maka diperlukan eko-efisiensi sebagai pengembangan efisiensi dengan memasukan aspek lingkungan. Ekoefisiensi adalah suatu konsep dengan mempertimbangkan aspek sumberdaya alam, energi dan lingkungan sehingga terwujud proses produksi yang dapat meminimumkan penggunaan bahan baku, air, dan energi serta dampak lingkungan per unit produk. Inovasi tersebut memberikan dampak yang baik berupa penghematan biaya dan ramah lingkungan serta peningkatan produktifitas. Penerapan atau pendampingan ini dilakukan di Kelompok Usaha Kecil Tahu "Sentosa Adi" yang terletak di dusun Dukuh kecamatan Mantrijeron Yogyakarta. Tahap awal yang dilakukan yaitu melakukan observasi untuk mengetahui kendala yang ada, misalnya kebersihan yang masih kurang, layout yang kurang baik, dan kapasitas mesin yang kecil. Tahap selanjutnya yaitu pemberian pelatihan untuk memberikan wawasan pentingnya eko-efisiensi bagi industri Tahu. Tahap berikutnya yaitu membuat usulan perbaikan dari kendala yang ditemukan. Beberapa usulan yang diperoleh yaitu re-layout tempat produksi, bahan bakar yang efisien, pengadaaan plat pemotong dan mesin press otomatis. Hasil akhir dari pendampingan tersebut yaitu pemberian alat potong tahu, guna mempercepat pemotongan, yang awalnya menggunakan pisau dan penggaris digantikan dengan alat pemotong yang lebih cepat. Alat tersebut dibuat dan disesuaikan dengan ukuran tahu yang diproduksi oleh IKM "Sentosa Adi" dan dibagikan kepada 17 pemilik usaha Tahu.
\end{abstract}

Kata-kata kunci: Eko-Efisiensi, produktivitas, IKM Tahu, Alat Pemotong

\section{Abstract}

Industrial development in this era is growing rapidly with increasing in basic needs, especially food needs. Tofu is one of food needs. The tofu industry needs an innovation that is production efficiency. Production efficiency is very important for the company to win the competition. With rapid industrial development, efficiency is not enough, eco-efficiency is 
advanced efficiency by including environmental aspects. Eco-efficiency is a concept of considering usage of natural resources and energy aspects or a production process that minimizes the use of raw materials, water, and energy as well as the environmental impact per unit of product. These innovations have good impacts of industrial management that results in cost savings, improving environmental performance and the organization. Ecoefficiency application or assistance is carried out in the "Sentosa Adi" Small and Medium Enterprise (SME) Group for Tofu and Tempe which is located in Mantrijeron Yogyakarta. For the initial stage, observation is conducted to find out existing problems, for example, lack of cleanliness, poor layout, and inadequate capacity. The next stage is providing a training to introduce the roles of eco-efficiency for SME Group "Sentosa Adi". The next stage is to make suggestions based on problems found in the previous stage. Some suggestions are production site re-layout, efficient fuel usage, providing cutting tools, and automatic press machines. The implemented suggestion is providing tofu cutting tools in order to speed up cutting process. These tools replace the use of a knife and a ruler to cut the tofu. The tools were made and adjusted to the size of tofu produced by SME Group "Sentosa Adi" and distributed to 17 tofu business owners.

Keywords : Eco-Efficiency, Productivity, SME Tofu, Cutting Tool

\section{PENDAHULUAN}

Dalam dunia industri, efisiensi produksi adalah hal yang sangat penting bagi perusahaan dalam memenangkan persaingan. Secara umum, efisiensi dapat diartikan sebagai ukuran tingkat penggunaan sumberdaya dalam suatu kegiatan atau proses tertentu. Semakin hemat (sedikit) sumberdaya yang kita gunakan untuk memproduksi produk dengan jumlah yang sama, produksi kita dikatakan semakin efisien (Utama et al., 2016).

Belakangan efisiensi saja tidak cukup, eko-efisiensi sebagai pengembangan efisiensi dengan memasukan aspek lingkungan. Eko-efisiensi adalah suatu konsep memasukkan aspek sumberdaya alam dan energi atau suatu proses produksi yang meminimumkan penggunaan bahan baku, air, dan energi serta dampak lingkungan per unit produk. Tujuan konsep ini adalah mengurangi dampak lingkungan per-unit yang diproduksi dan dikonsumsi. Dengan mengurangi sumberdaya yang diperlukan bagi terbentuknya produk/pelayanan yang lebih baik, maka bisnis dapat mencapai keuntungan lebih baik. Eko-efisiensi memberikan manfaat dengan menggunakan tata kelola yang apik (good house keeping). Perusahaan yang mengimplementasikan tata kelola yang apik akan memperoleh penghematan biaya, kinerja lingkungan hidup yang lebih baik, dan pembelajaran organisasi (Good Housekeeping Manual, 2006).

Salah satu industri yang berlokasi di Kota Yogyakarta adalah industri pembuatan tahu. Tahu merupakan makanan tradisional bagi penduduk Indonesia, sehingga tidak terdapat data yang pasti mengenai waktu mulai adanya industri tahu di Indonesia. Sebagai upaya untuk meningkatkan kesadaran para pengusaha tahu tentang efisiensi produksi dan tata kelola industri yang apik, maka Dinas Perindustrian Kota Yogyakarta dan Program Studi Teknik Industri - UIN Sunan Kalijaga Yogyakarta melaksanaan kegiatan pendampingan Industri Kecil dan Menengah Tahu.

\section{METODE PELAKSANAAN}

Program peningkatan eco-efisiensi dan produktivitas IKM Tahu bertempat di desa Dukuh Kecamatan Mantrijeron Yogyakarta. Program ini dilaksanakan dalam bentuk pendampingan kepada IKM Tahu. Ada 17 (tujuh belas) IKM Tahu yang menjadi objek dari pendampingan ini yang tergabung dalam Kelompok Usaha Kecil Tahu dan Tempe "Sentosa 
Adi”, di bawah pimpinan Bapak Widodo. Ketujuh belas IKM Tahu tersebut ditampilkan pada tabel 1 .

Tabel 1. Daftar IKM Tahu

\begin{tabular}{|l|c|}
\hline No. & IKM Tahu \\
\hline 1. & Bapak Ponijan \\
\hline 2. & Bapak Suparjo \\
\hline 3. & Ibu Apriyanti \\
\hline 4. & Ibu Ayem \\
\hline 5. & Ibu Endang \\
\hline 6. & Bapak Pramuji \\
\hline 7. & Bapak Cahyo \\
\hline 8. & Bapak Girih \\
\hline 9. & Bapak Giyat \\
\hline 10. & Ibu Surya \\
\hline 11. & Ibu Sumi \\
\hline 12. & Bapak Pangat \\
\hline 13. & Puji Hartanto \\
\hline 14. & Tri Diningsih \\
\hline 15. & Erlik Wulandari \\
\hline 16. & Shinta Dewi \\
\hline 17. & Widodo \\
\hline
\end{tabular}

Kegiatan pendampingan dilaksanakan dengan melibatkan Dosen dan Mahasiswa Teknik Industri UIN Sunan Kalijaga. Pendampingan dimulai pada bulan Maret hingga bulan Juni 2019. Pendampingan ini berjalan atas kerjasama anatara Dinas Perindustrian Kota Yogyakarta bekerjasama dengan Program Studi Teknik Industri UIN Sunan Kalijaga. Adapun rancangan kegiatan pendampingan ini meliputi 3 (tig) tahap, yaitu:

1. Observasi dan Pre-assesment IKM Tahu

2. Pelatihan

3. Usulan perbaikan gambar 1 .

Kegiatan pendampingan IKM Tahu ini dilaksanakan mengacu pada diagram alir pada

\section{HASIL DAN PEMBAHASAN}

\subsection{Observasi dan Pre-assesment IKM Tahu}

Berisi hasil pelaksanaan kegiatan, kendala yang dihadapi serta dampak dan upaya keberlanjutan kegiatan. Hasil dapat dilengkapi dengan tabel, grafik, gambar maupun bagan. Kegiatan observasi dan pre-assesment merupakan kegiatan yang pertama kali dilaksanakan dalam pendampingan ini. Kegiatan ini dilaksanakan pada bulan April 2019 hingga Mei 2019. Dari kegiatan ini dapat diketahui kendala dan masalah yang dihadapi oleh IKM Tahu dalam kegiatan produksi mereka. 




Gambar 1. Diagram Alir Kegiatan Pendampingan IKM Tahu

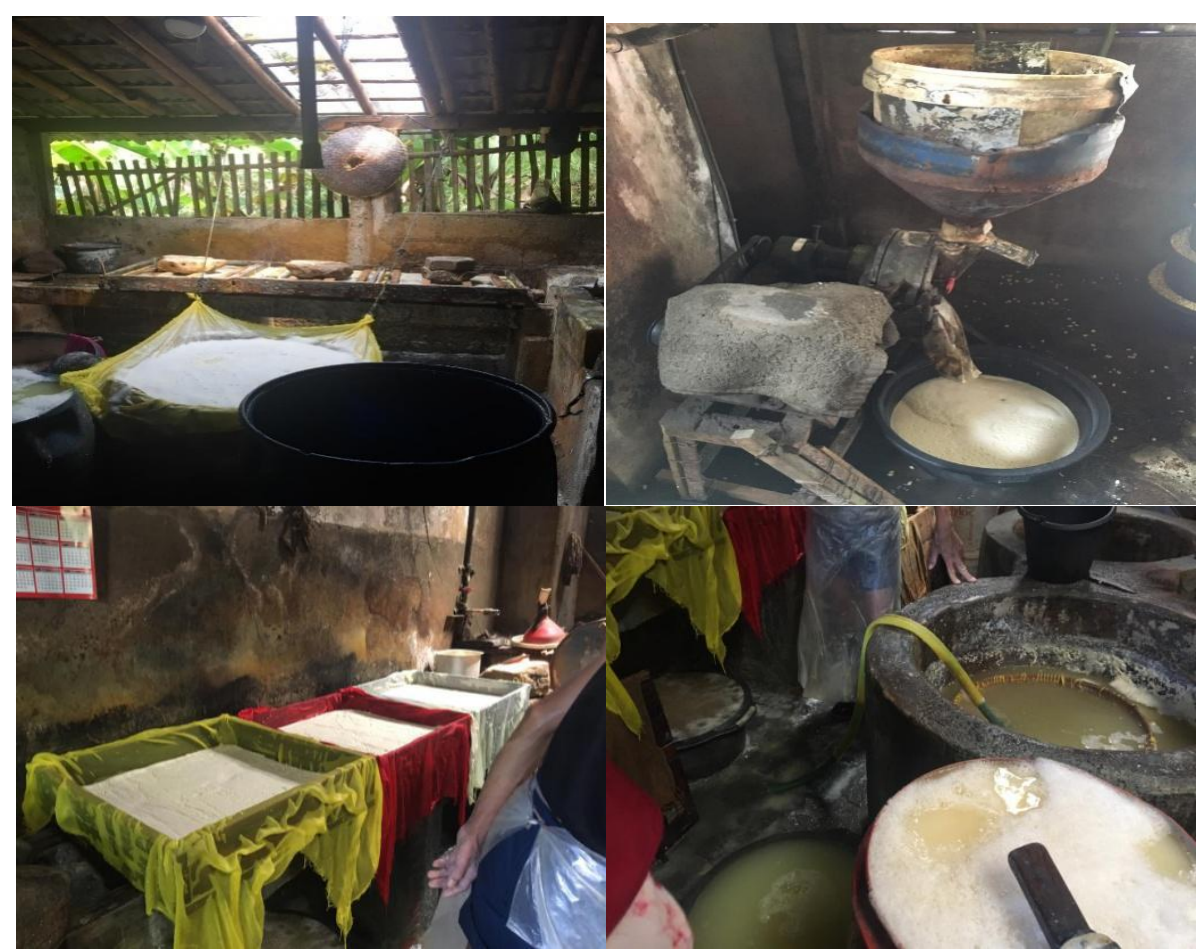




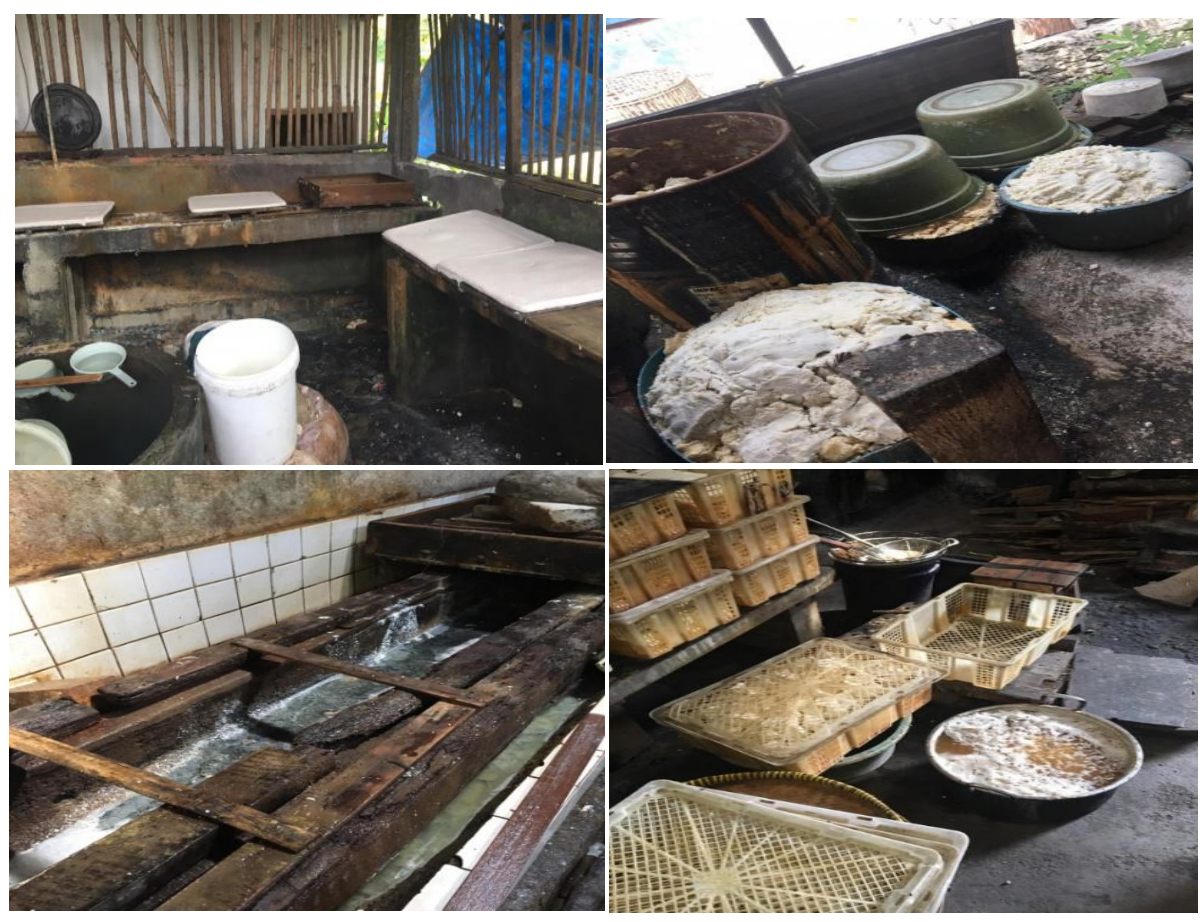

Gambar 2. Pre-assesment dan obervasi IKM Tahu Dusun Dukuh Mantrijeron, Yogyakarta

Hasil observasi dan pre-assesment pada 17 (tujuh belas) IKM Tahu wilayah Mantrijeron, Yogyakarta diperoleh beberapa identifikasi masalah, yaitu:

1. Kebersihan pekerja dana ruangan yang kurang

2. Layout Tempat Produksi yang masih tidak efisien

3. Saluran pembuangan air belum tersedia

4. Penempatan Limbah Padat tidak layak

5. Ketergantungan sumber listrik hanya dari PLN

6. Masih bergantung dengan kayu bakar

7. Kapasitas mesin giling masih kecil

8. Pemotongan tahu masih manual

9. Press tahu yang masih manual

10. Belum ada packaging tahu siap jual yang baik.

11. Pencahayaan dan sirkulasi udara yang kurang

Dari Hasil observasi diketahui bahwa IKM tersebut mengalami pemborosan pada proses produksinya. Hal ini sesuai dengan pernyataan Gasperzs (2008) yang mengatakan bahwa Beberapa akar penyebab dari variasi dan pemborosan ditempat kerja adalah :

a. Tata Letak pabrik dan kantor yang jelek,

b. Waktu setup peralatan dan mesin yang panjang (lama),

c. Organisasi tempat kerja yang jelek,

d. Pelatihan yang tidak dapat dan/atau tidak cukup,

e. Metode kerja yang tidak standar,

f. Tidak mengikuti prosedur-prosedur dan intruksi-intruksi kerja,

g. Kapabiltas proses yang rendah secara statistik,

h. Perencanaan yang jelek,

i. Masalah-masalah kualitas material dengan pemasok

j. Peralatan pengukuran yang tidak akurat, 
k. Lingkungan kerja yang buruk (sebagai misal: lampu penerangan, panas, kelembaban, kebersihan dan kenyamanan, dll).

Untuk itu maka diperlukan perbaikan perbaikan untuk mengurangi pemborosan.

\subsection{Pelatihan}

Pelatihan IKM Tahu dilaksanakan pada tanggal 2 Mei 2019, yang bertempatkan di Unit Pengelolaan Teknis Dinas Perindustrian dan Perdagangan (UPT Disperindag) Yogyakarta yang berada di area Pasar Satwa dan Tanaman Hias Yogyakarta (PASTY), Yogyakarta. Pelatihan ini berjudul "Pelatihan Pencapaian Efisiensi Produksi". Narasumber dari pelatihan IKM Tahu merupakan dosen dari Teknik Industri UIN Sunan Kalijaga, yaitu; Bapak Cahyono Sigit Pramudyo, S.T., M.T., D.Eng. dengan judul materi pelatihan "Produksi Bersih Industri Kecil dan Menengah Produk Tahu" dan Ibu Dwi Agustina Kurniawati, S.T., M.Eng., Ph.D. dengan judul materi pelatihan "Peningkatan Efisiensi dan Produktivitas IKM Tahu".

Kegiatan pelatihan ini diberikan kepada 17 IKM Tahu. Kegiatan ini sangat penting guna memberikan kesadaran kepada para pengusaha IKM tahu akan pentingnya menjalankan produksi secara efisien dan produktf serta tetap memperhatikan aspek lingkungan (ecoefisiensi). Di awal pelatihan banyak peserta yang belum paham urgensi eco-efisiensi dan perlunya meningkatkan produtivitas, karena mereka banyak yang menjalankan usaha seadanya saja. Di akhir pelatihan dilakukan sesi tanya jawab dan juga tukar fikiran serta brain storming dengan peserta IKM terkait apa saja yang dapat mereka lakukan guna mengimplementasikan eco-efisiensi dan meningkatkan produktivitas mereka.

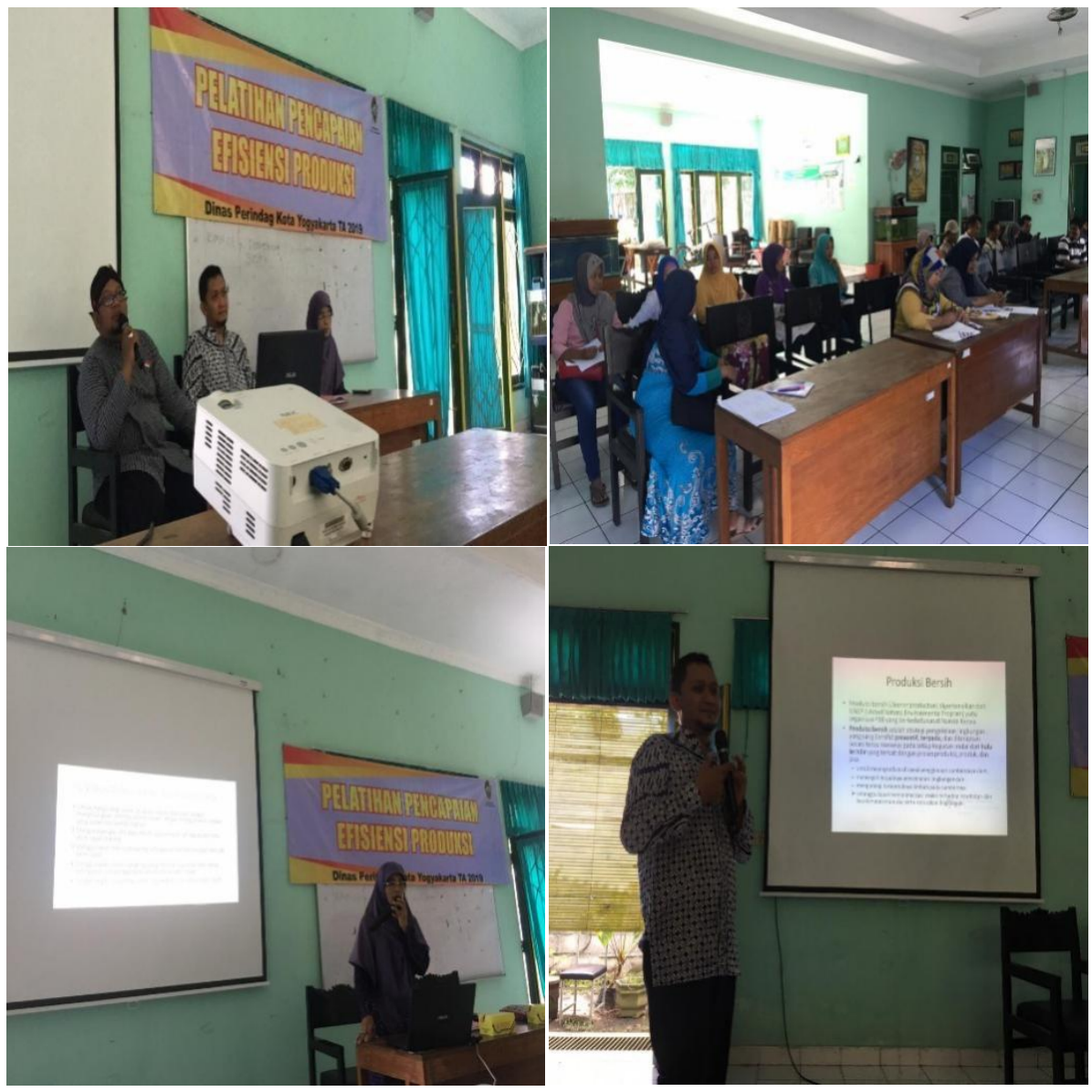

Gambar 3. Pelatihan Eco-efisiensi IKM Tahu 


\subsection{Usulan Perbaikan}

Dari hasil pre-assesment dan identifikasi masalah, serta setelah melakukan beberapa diskusi dan Focus Group Discussion dengan tim Pendampingan dan juga dengan pelaku IKM Tahu, maka diperoleh beberapa usulan perbaikan dalam rangka peningkatan efisiensi pada IKM Tahu. Usulan perbaikan untuk IKM Tahu yaitu:

1. Re-layout tempat produksi

2. Penggunaan bahan bakar yang lebih efektif dan ramah lingkungan

3. Plat pemotong tahu

4. Mesin steamer pembuat tahu

5. Mesin giling kedelai dengan kapasitas lebih besar

6. Alat press otomatis

7. Pemakaian sarung tangan saat produksi

8. Pembuatan saluran pembuangan air sisa produksi

9. Alat packaging tahu yang sudah siap jual

10. Perlu pembuatan ventilasi udara dan pencahayaan

Dari semua usulan perbaikan di atas, maka usulan no 3, yaitu penyediaan plat pemotong tahu, merupakan usulan yang memungkinkan untuk direalisasikan. Hal itu karena mempertimbangkan ketersediaan dana yang tersedia dari program pendampingan Disperindag Kota Yogyakarta yang ada. Untuk itu, maka usulan rekomendasi berupa penyediaan alat pemotong tahu berbahan dasar kayu sebagai kotaknya dan senar sebagai pemotongnya. Plat pemotong tahu tersebut memiliki ukuran 10 kotak x 10 kotak $=100$ kotak (ukuran papan $52 \mathrm{~cm} \times 52 \mathrm{~cm}$ ). Masing-masing IKM Tahu mendapat 1 alat pemotong tahu. Serah terima alat pemotong tahu dilaksanakan di IKM Tahu Dusun Dukuh dengan menghadirkan 17 IKM Tahu beserta perwakilan dari Disperindag Kota Yogyakarta.

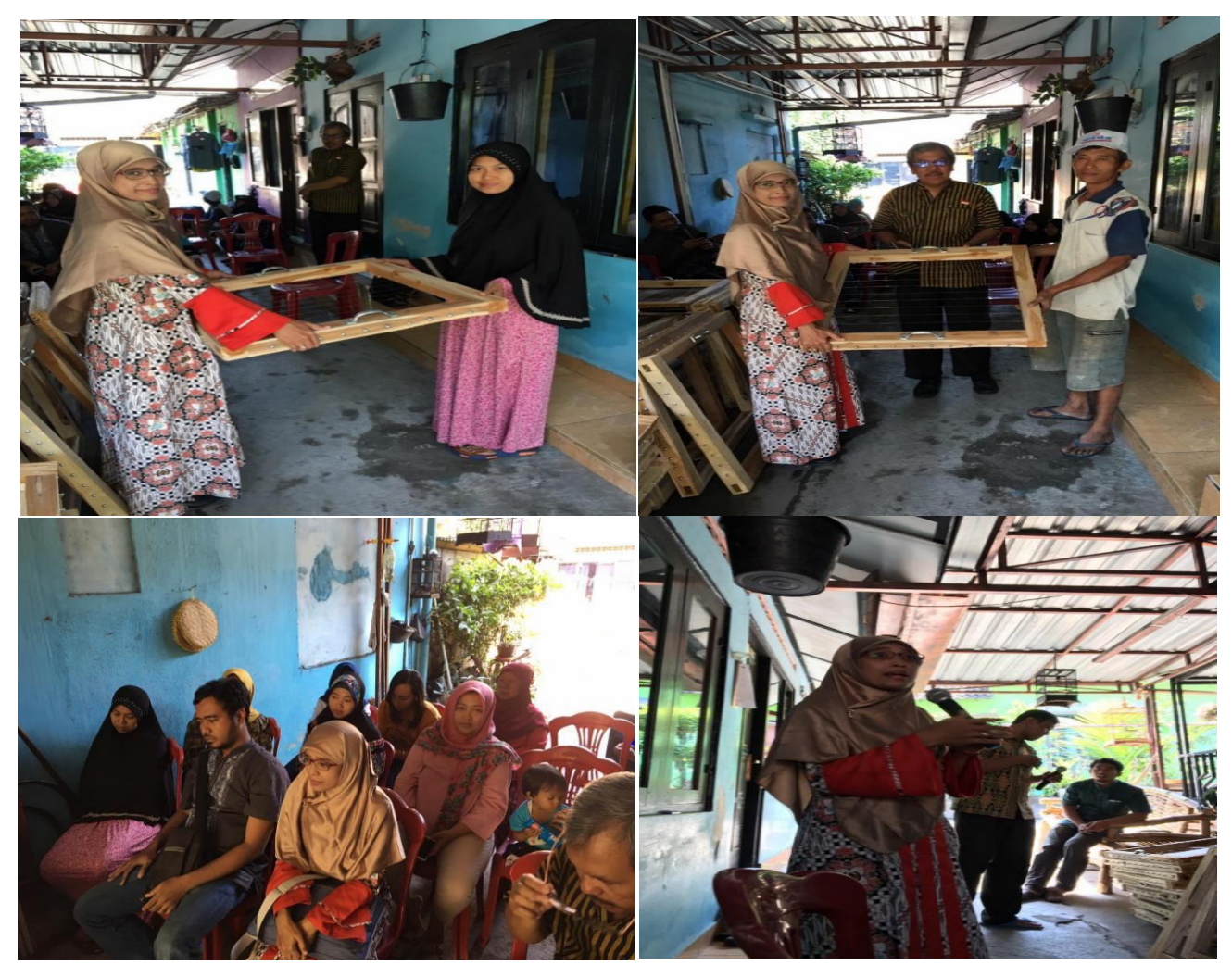

Gambar 4. Serah terima alat bantu pemotong tahu pada 17 IKM hahu di desa Dukuh 
Dengan penyediaan alat pemotong tahu maka proses pemotongan tahu dapat lebih cepat karena tidak perlu melakukan pengukuran dan pemotongan secara manual (dengan penggaris dan pisau) sehingga pemotongan tahu dapat menjadi lebih efisien dan lebih bersih (eco-efisiensi). Sehingga penyediaan alat pemotong tahu dapat meingkatkan produktivitas IKM Tahu.

\section{KESIMPULAN}

IKM Tahu merupakan sentra industry kecil yang menjalankan produksinya dengan teknologi dan pengetahuan yang seadanya. Untuk itu diperlukan adanya program pendampingan IKM Tahu. Prodi Teknik Industri dan Disperindag kota Yogyakarta bekerjsama untuk melakukan kegiatan pendampingan IKM Tahu di desa Dukuh, kecamatan Mantrijeron, Yogyakakarta. Tema yang diangkat yaitu peningkatan Eco-efisiensi dan produktivitas IKM Tahu. Kegiatan ini meliputi 3 tahap kegiatan, yaitu pre-assesment dan obesrvasi lapangan. Kemudian dilanjutkan dengan kegiatan pelatihan pda 17 IKM Tahu di dusun Dukuh. Pelatihan ini diperlukan untuk meningkatkan kesadaran dan pengetahuan para pengusaha IKM tahu akan pentingnya eco-efisiensi dan peningkatan produktifitas bagi usaha mereka. Disamping itu juga memberikan pengetahuan pada mereka apa saja hal-hal kecil dan sederhana yang dapat dilakukan untuk efisiensi produksi. Di akhir pendampingan, dilakukan FGD untuk menentukan usulan perbaikan dengan mempertimbangakn keterbatasan dana yang ada. Hasilnya yaitu usulan berupa alat pemotong tahu berbahan dasar kayu dan senar. Meskipun alat pemotong tahu ini belum maksimal dalam mebantu peningkatan efisisensi para pengusaha IKM tahu, tetapi sudah dapat membantu proses pemotongan tahu menjadi lebih cepat dan lebih bersih (eco-efisiensi) sehingga diharapkan produktivitas meningkat.

Untuk pendampingan selanjutnya, maka diharapkan adanya alokasi dana yang lebih besar sehingga solusi-solusi yang diberikan dalam rangka peningkatan eco-efisiensi dan produktifitas para pengusaha IKM tahu dapat lebih signifikan.

\section{UCAPAN TERIMA KASIH}

Ucapan terimakasih kami sampaikan kepada Dinas Perindustrian dan Perdagangan (Disperindag) Kota Yogyakarta yang telah memfasilitasi dan memberikan dukungan dana sehingga kegiatan pengabdian masyarakat untuk para pengusaha IKM Tahu di Desa Dukuh, Mantrijeron, Yogyakarta dapat terlaksana dengan baik. Terimakasih juga kami sampaikan kepada pak Widodo selaku kepala paguyuban IKM Tahu dan Tempe "Sentosa Adi" dan Ibu Sintha selaku tuan rumah pada saat tahap observasi dan serah terima yang telah membantu kelancaran program pendampingan ini. Juga kerjasama yang positif pada semua pelaku IKM Tahu Desa Dukuh. Semoga kerjasama baik ini tetap terjalin dan terus berkembang.

\section{DAFTAR PUSTAKA}

Alfiana, I. 2018. Pengukuran Tingkat Eco Effisiensi Pada IKM Tahu (Studi Kasus : IKM Tahu Pak Tasmin Pati). Undergraduate thesis, Fakultas Teknologi Industri UNISSULA.

Gasperz, V. 2008. The Executive Guide to Implementing Lean six sigma : strategi dramatis reduksi cacat/kesalahan, biaya, inventori, dan lead time dalam waktu kurang dari 6 bulan. Jakarta : PT Gramedia Pustaka Utama.

Good Housekeeping Manual. 2006. Bonn, Germany: GTZ - P3U and PREMAnet e. V.

Rifa'atussa'adah dan Prabawani, B. 2017. Analisis Eko-Efisiensi pada Usaha Kecil dan Menengah (UKM) Batik Tulis Bakaran (Studi Kasus Pada Batik Tjokro). Diponegoro

Journal of Social and Politic. Hal. 1-6. 
Sumberrejeki2201.blogspot.com. (2019, 3 Juli). Jual Alat-Alat Tahu. Diakses pada 3 Juli 2019, dari http://sumberrejeki2201.blogspot.com/2015/12/jual-alat-alattahu.html?m=1.

Utama, A. P., Wahyono, H., Witjaksono, M. 2016.. Efisiensi Pengambilan Keputusan Sumberdaya Ekonomi Konsumsi Produksi Mahasiswa. Jurnal Pendidikan: Teori, Penelitian, dan Pengembangan, 1(4), 712-716. 